\begin{tabular}{|} 
Ambiente \& Água - An Interdisciplinary Journal of Applied Science \\
ISSN 1980-993X - doi:10.4136/1980-993X \\
www.ambi-agua.net \\
E-mail: ambi.agua@gmail.com
\end{tabular}

\title{
Bioconcentration and bioaccumulation of toxic metals in Scirpus californicus from natural wetlands in the Central Andes of Peru
}

\author{
ARTICLES doi:10.4136/ambi-agua.2728
}

Received: 27 Mar. 2021; Accepted: 16 Jul. 2021

\section{Lesly Aguilar Boleji1 ${ }^{1 D}$; María Custodio-Villanueva ${ }^{2}$; Fernán Cosme Chanamé Zapata ${ }^{3 * i D}$; Walter Javier Cuadrado Campó ${ }^{4}$; Richard Pavel Peñaloza Fernández ${ }^{5}$ (D)}

\footnotetext{
${ }^{\mathbf{1}}$ Facultad de Zootecnia. Universidad Nacional del Centro del Perú (UNCP), Avenida Mariscal Castilla, n³089, 12400, Huancayo, Perú. E-mail: 47197553ab@gmail.com

${ }^{2}$ Facultad de Medicina. Centro de Investigación en Alta Montaña (CIAM). Universidad Nacional del Centro del Perú (UNCP), Avenida Mariscal Castilla, n³089, 12400, Huancayo, Perú. E-mail: mcustodio@uncp.edu.pe

${ }^{3}$ Facultad de Zootecnia. Centro de Investigación en Alta Montaña (CIAM). Universidad Nacional del Centro del Perú (UNCP), Avenida Mariscal Castilla, n³089, 12400, Huancayo, Perú.

${ }^{4}$ Facultad de Ciencias Aplicadas. Universidad Nacional del Centro del Perú (UNCP), Carretera Central, Km 4.5, 12651, Tarma, Perú. E-mail: wjcuadrado@hotmail.com

${ }^{5}$ Facultad de Zootecnia. Universidad Nacional del Centro del Perú (UNCP), Avenida Mariscal Castilla, n³089, 12400, Huancayo, Perú. E-mail: drach_89@ hotmail.com

*Corresponding author. E-mail: fernan_chz@hotmail.com
}

\begin{abstract}
Bioconcentration and bioaccumulation levels of lead, zinc, iron and arsenic in Scirpus californicus of the Paca and Tragadero Lagoons, Jauja, Peru, were evaluated. Water, sediment and Scirpus californicus samples were collected from each lagoon, which were transported to the laboratory for the analytical determination of lead, iron, zinc and arsenic, which was performed by atomic absorption spectrophotometry based on the methodology recommended by FAO. The results obtained reveal the current status of the quality of the aquatic environment of natural wetlands in the central region of Peru in terms of heavy metals and arsenic, which provide an important source of water for the populations of large cities in the central region of Peru. The presence of heavy metals and arsenic with great impact on the quality of these water bodies may be due to the pressure exerted by anthropogenic activities such as mining, agriculture, industrial and domestic wastewater. The sediments of Paca and Tragadero Lagoons showed high concentrations of $\mathrm{Fe}$, exceeding international standards. Aquatic vegetation represented by Scirpus californicus in both lagoons bio accumulated mainly $\mathrm{Zn}$, without exceeding international standards.
\end{abstract}

Keywords: bioaccumulation factor, bioconcentration factor, heavy metals, lagoons, Scirpus californicus.

\section{Bioconcentração e bioacumulação de metais tóxicos em Scirpus californicus de áreas úmidas naturais nos Andes Centrais do Peru}

\section{RESUMO}

Foram avaliados os níveis de bioconcentração e bioacumulação de chumbo, zinco, ferro e arsênio em Scirpus californicus das lagoas Paca e Tragadero, Jauja, Peru. Amostras de água, 
sedimento e Scirpus californicus foram coletadas de cada lagoa, as quais foram transportadas ao laboratório para a determinação analítica de chumbo, ferro, zinco e arsênio que foi realizada por espectrofotometria de absorção atômica com base na metodologia recomendada pela FAO. Os resultados obtidos revelam o estado atual da qualidade do ambiente aquático dos pântanos naturais da região central do Peru em termos de metais pesados e arsênio que constituem uma importante fonte de água para as populações de grandes cidades da região central do Peru. A presença de metais pesados e arsênio com grande impacto na qualidade desses corpos d'água pode ser decorrente da pressão exercida por atividades antrópicas como mineração, agricultura, efluentes industriais e domésticos. Os sedimentos das lagoas Paca e Tragadero apresentaram altas concentrações de $\mathrm{Fe}$, superando os padrões internacionais. A vegetação aquática representada por Scirpus californicus em ambas as lagoas mostra bioacumulação principalmente de $\mathrm{Zn}$, sem ultrapassar os padrões internacionais.

Palavras-chave: fator de bioacumulação, fator de bioconcentração, lagoas, metais pesados, Scirpus californicus.

\section{INTRODUCTION}

Lagoons are among the most important ecosystems in the world, but due to significant anthropogenic impacts there is a high degree of contamination of the aquatic environment. It is therefore necessary to have a permanent monitoring program to prevent further deterioration and the risk of people using contaminated water and consuming waters with metals that are harmful to health (Odjer-Bio et al., 2015). Contamination of aquatic ecosystems by heavy metals and metalloids has been a serious concern worldwide for many decades and has caused devastating effects on aquatic organisms. Consequently, frequent monitoring of these metals in water and fish is important to ensure the safety of fish consumers in the area (Owolabi and Awodele, 2019).

Heavy metals are the group of pollutants of greatest interest due to their potential toxicity, persistence and bioaccumulation (Kara et al., 2017). In aquatic environments, these toxic elements can be released from sediment through adsorption and desorption processes, which prolongs the residence time of heavy metal contamination, constituting an important source of contamination for the water column (Hassan et al., 2015). Degradation of water quality by these metals leads to serious risks to human health and ecosystems, loss of biodiversity and deterioration of environmental quality (Hou et al., 2019).

Several studies have been published in developed and undeveloped countries on the anomalous distribution of metals in water and sediments, which are very important data for understanding the behavior of metals in aquatic environments. It is important to identify the concentration of metals in biota and to consider their potential impact on the food chain and the risk to human health (Singh et al. 2014).

The bioconcentration and bioaccumulation of heavy metals and metalloids (e.g., arsenic) in tissues is a result of the concentrations in water and sediment (Voigt et al., 2015) and are indicators of water and sediment contamination, becoming a useful tool to study the biological role of metals present in aquatic organisms that tend to accumulate contaminants in their tissues (Shah et al., 2009). Therefore, the determination of heavy metals in water, sediment and macroinvertebrate tissues are important points of natural ecological risk assessment in aquatic systems and to estimate the load of heavy metal contamination in biota, by means of the bioaccumulation factor (Santoro et al., 2009).

It has been proven that aquatic plants known as Scirpus californicus "cattail", which are located in the benthic zones of the lagoons, present specific characteristics for the bioaccumulation of heavy metals in their roots and stems. Therefore, it is considered as a plant that can be used for the bioremediation of contaminated waters and soils (Rodríguez Ayala et 
al., 2018).

Despite the increasing impact of heavy metal pollution due to urban growth and agricultural and mining activities, few studies have focused on the behavior and relationships of these pollutants on the biotic and abiotic components of aquatic environments (MendozaCarranza et al., 2016).

In Peru, high Andean wetland water bodies continue to be the least studied and represent one of the most threatened ecosystems. The decline in water quality in these ecosystems is mainly due to inadequate management, despite the fact that they play a fundamental role in human well-being and are important for maintaining ecological balance and biodiversity (Urviola, 2009).

In this context, the objective was to evaluate the bioconcentration and bioaccumulation levels of lead, zinc, iron and arsenic in water, sediment and aquatic vegetation of the Paca and Tragadero Lagoons in the Central Andes of Peru.

\section{MATERIAL AND METHODS}

\subsection{Study area}

The Paca and Tragadero Lagoons are located in the Junín region, in the Central Andes of Peru, in the northeastern Mantaro Valley at $11^{\circ} 46^{\prime} 48^{\prime \prime} \mathrm{S}$ and $75^{\circ} 30^{\prime} 13^{\prime \prime} \mathrm{N}$, at an altitude ranging from 3725 to 3750 m.a.s.l. The two lagoon systems have an area covered by emergent and submerged macrophytes dominated by cattails. The climate of the region is cold, with a mean annual temperature of $11.4^{\circ} \mathrm{C}$ and an annual rainfall of $649 \mathrm{~mm}$, and the summer (January to March) is the rainy seasons (Figure 1).
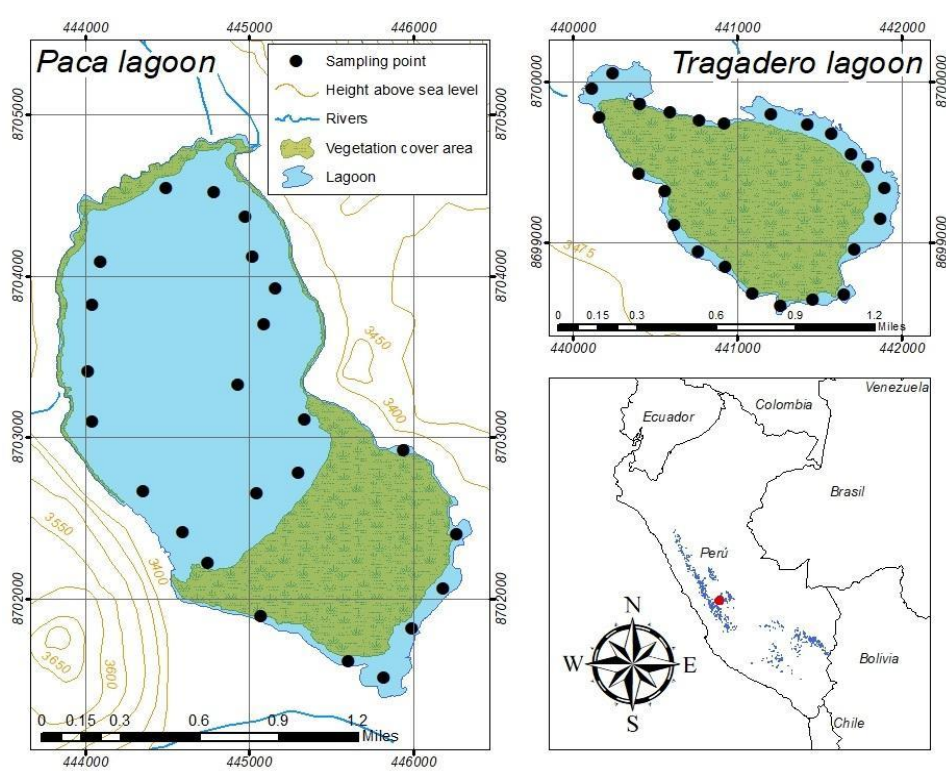

Figure 1. Location of sampling points in Paca and Tragadero Lagoons.

\subsection{Collection of water, sediment and Scirpus californicus samples}

The water, sediment and Scirpus californicus samples were collected in six sampling stations (with four sampling sites per station and lagoon) during 2018.

The water samples were collected at each sampling site, making a total of 24 samples for each lagoon. The water samples were collected on the shore and in the middle part of each lagoon, in the rainy season. At each sampling site, one liter of water was collected in 1.5-liter plastic bottles, previously treated with a $10 \%$ nitric acid solution for 24 hours and rinsed with deionized water and raw water from the sampling site (Custodio et al., 2020). 
Sediment samples were collected at the same sampling sites, making a total of 24 samples for each lagoon, using an Ekman-type dredge. Subsequently, they were placed in plastic buckets in order to facilitate the settling of sediment and to eliminate the supernatant and then be placed in polypropylene bags. The water and sediment samples were conditioned in a separate cooler under refrigerated conditions $\left(4^{\circ} \mathrm{C}\right)$ and were sent to the laboratory for analysis.

Scirpus californicus samples were collected at the same sampling sites, making a total of 24 samples for each lagoon. The composite samples consisted of three simple samples of Scirpus californicus leaves collected on the shore and the existing islands of each lagoon, for which suitable gardening tools were used to facilitate collection. Each composite sample was labeled and placed on meshes to prevent deterioration. The determination of heavy metals in the water, sediment and aquatic vegetation samples was carried out at the Analytical Chemistry and Environment Laboratory of the Universidad Nacional del Centro del Perú.

\subsection{Analytical determination}

The water samples were filtered through $0.45 \mathrm{~mm}$ membrane filters. The digestion of the samples was carried out with $250 \mathrm{ml}$ of water, brought to boiling until $100 \mathrm{~mL}$ were obtained. Then, $5 \mathrm{~mL}$ of nitric acid and $5 \mathrm{~mL}$ of concentrated hydrochloric acid were added for the destruction of organic matter and again it was brought to boiling (until the water was consumed and a residue of pasty consistency was obtained). It was allowed to cool; then $10 \mathrm{~mL}$ of distilled water were added, and the mixture was filtered and gauged in a fiola of $100 \mathrm{~mL}$, with nitric acid to $1 \%$ (APHA et al., 2012).

The sediment was then dewatered and sieved through a $2 \mathrm{~mm}$ stainless steel mesh sieve to remove stones and plant debris. The sieved sediment was placed in an electric oven at $60^{\circ} \mathrm{C}$ for $24 \mathrm{~h}$ and the completely dry samples were pulverized in a windmill. Then, $1 \mathrm{~g}$ of each sediment sample was weighed into a $100 \mathrm{~mL}$ beaker and $10 \mathrm{~mL}$ of nitric acid was added and allowed to act for a few seconds for disintegration of the organic matter. Then $10 \mathrm{~mL}$ of hydrochloric acid was added and allowed to act for one minute to dissolve the salts. It was then boiled for five minutes until the sample achieved a pasty consistency, when it was removed from the stove and again $10 \mathrm{~mL}$ of hydrochloric acid was added to dissolve the remains adhered to the walls of the beaker. Subsequently, the sample was transferred to a $100 \mathrm{~mL}$ beaker, for homogenization and gauged with distilled water to $100 \mathrm{~mL}$, then it was filtered.

Scirpus californicus leaves were shade-dried and then pulverized in a grinder and $0.5 \mathrm{~g}$ of each sample was weighed into a $100 \mathrm{~mL}$ beaker. Then, $10 \mathrm{~mL}$ of nitric acid was added and made to stand for half an hour for disintegration of the organic matter. Then, it was boiled for five minutes until it acquired a pasty consistency, when it was gauged with distilled water and $10 \mathrm{~mL}$ of hydrochloric acid was added and left to act for one minute to dissolve the remains adhered to the walls of the beaker. Later, it was boiled. Since the mixture included big particles, it was homogenized and gauged with distilled water, and it was then filtered.

The concentration of $\mathrm{Cu}, \mathrm{Fe}, \mathrm{Pb}, \mathrm{Zn}$ and $\mathrm{As}$ in water (mg L-1), sediment and Scirpus californicus (mg kg-1) was determined by flame atomic absorption spectrophotometry using an AA-6800 Atomic Absorption Spectrophotometer, Varian AA240.

\subsection{Quality control and assurance}

The quality of the analytical data was assured by the application of quality control methods in the laboratory, including the use of standard operating procedures (Table 1). All analyses were performed in triplicate and the results were expressed as the mean. Instrument calibration standards were prepared by diluting the $1000 \mathrm{ppm}$ standard solution for $\mathrm{Pb}$ (1.19776.0500), $\mathrm{Zn}$ (1.19806.0500), Fe (1.19781.0500) and As (1.19773.0500) supplied by Merck (Germany) at the highest purity level (99.98\%). All glass materials were treated with $10 \%$ nitric acid for 24 hours, rinsed with deionized water several times and oven-dried before use. 
Table 1. Analytical conditions for the measurement of heavy metals in a sample solution using AAS.

\begin{tabular}{ccccccccc}
\hline Analyte & $\begin{array}{c}\text { Wavelength } \\
(\mathrm{nm})\end{array}$ & $\begin{array}{c}\text { Slit } \\
(\mathrm{nm})\end{array}$ & $\begin{array}{c}\text { Lamp } \\
\text { current } \\
(\mathrm{mA})\end{array}$ & Mode & $\begin{array}{c}\text { Calibration } \\
\text { range } \\
(\mathrm{mg} \mathrm{L}-1)\end{array}$ & $\begin{array}{c}\text { Limit of } \\
\text { detection } \\
(\mathrm{mg} \text { L-1 })\end{array}$ & $\begin{array}{c}\text { Deviation } \\
(\%)\end{array}$ & $\begin{array}{c}\text { Recovery } \\
(\%)\end{array}$ \\
\hline $\mathrm{Pb}$ & 217.0 & 1.0 & 10.0 & GF-AAS & $0.25-10.0$ & 0.010 & 4.7 & 99.80 \\
$\mathrm{Zn}$ & 213.9 & 1.0 & 5.0 & GF-AAS & $0.25-1.5$ & 0.001 & 8.2 & 99.60 \\
$\mathrm{Fe}$ & 248.3 & 0.2 & 5.0 & GF-AAS & $1.0-10.0$ & 0.006 & 5.8 & 97.70 \\
$\mathrm{As}$ & 193.7 & 0.2 & 10.0 & HG-AAS & $0.005-0.1$ & 0.001 & 8.52 & 109.39 \\
\hline
\end{tabular}

\subsection{Statistical analysis}

The Kruskal-Wallis test was used to compare the median concentrations of heavy metals in water, sediment and aquatic vegetation, given the nature of the distribution of environmental variables (Kruskal and Wallis, 1952).

To quantify the absorption capacity of Scirpus californicus quotient of the mean concentrations in relation to the sediment, the transfer or bioaccumulation factor was calculated as the of elements in the leaf and sediment (Peris et al., 2007) (Equation 1).

$$
F B A=\frac{C_{\text {plant }}}{C_{\text {sediment }}}
$$

The bioconcentration factor (BCF) was calculated as the ratio between the concentration of elements in the plant and the concentration of the element in the water (Fernández et al., 2018) (Equation 2).

$$
F B C=\frac{C_{p}}{C_{A}}
$$

\section{RESULTS AND DISCUSSION}

\subsection{Concentration of $\mathrm{Pb}, \mathrm{Zn}, \mathrm{Fe}$ and $\mathrm{As}$ in water from Paca and Tragadero Lagoons}

Regarding the concentration of elements in water in Paca and Tragadero (Table 2), the results show that $\mathrm{Pb}$ concentrations exceeded the standards in Tragadero and were at the limit in Paca, according to Canadian water standards (Canadian Council of Ministers of the Environment, 2001) and the environmental quality standard for water (EQS) established by Peruvian legislation for $\mathrm{Pb}$ of $0.01 \mathrm{mg} \mathrm{L}-1$ (MINAM, 2017). In the case of $\mathrm{Zn}$, in both lagoons the values are lower than the EQS of $1 \mathrm{mg}$ L-1. For Fe concentrations, the concentrations in both lagoons did not exceed the EQS of $0.3 \mathrm{mg} \mathrm{L}-1$; while for As, the values found in Tragadero are significantly higher than the EQS of $0.01 \mathrm{mg} \mathrm{L}-1$ and in Paca did not exceed this value.

The high values of $\mathrm{Pb}$ and As, are not typical of natural waters (Altun et al., 2009), whose values were high during the sampling period in each lagoon presented high variability, possibly due to the presence of different anthropogenic sources, exceeding the EQS for water (MINAM, 2017), especially in Tragadero. These sources usually have high impact on metal concentrations in the lagoons; however, surface runoff from the surrounding soil can result in the transport of these contaminants to water bodies (Singh, 2001).

In the case of As, a high concentration was found, possibly determined by the effect of the soil around the lagoon, which retains and distributes these elements and can act as sources after rainfall. The mineralogical composition of the soil is a very important factor that determines the mobility of As, depending on the environmental conditions (Martínez-López et al., 2020). The high values of As entering the lagoons through the watercourses are susceptible to mobilization from the soil and sediment due to agricultural practices (Fayiga and Saha, 2016).

On the other hand, domestic activities such as laundry and industrial activities operating in the area may represent a primary source of $\mathrm{Zn}$, widely used in detergents and deodorant soaps in the form of zinc oxide, according to US Patent 19 (Lieberman and Ogden, 1998). 
Table 2. Descriptive statistics of heavy metals and arsenic in water from Paca and Tragadero Lagoons in the Central Andes of Peru, expressed in mg L-1.

\begin{tabular}{|c|c|c|c|c|c|c|c|c|}
\hline \multirow{2}{*}{ Element } & \multirow{2}{*}{$\begin{array}{l}\text { Descriptive } \\
\text { statistic }\end{array}$} & \multicolumn{2}{|c|}{ Lagoons } & \multirow{2}{*}{$\begin{array}{c}\text { WHO } \\
\begin{array}{c}\text { Drinking water } \\
\text { guidelines }\end{array}\end{array}$} & \multirow{2}{*}{$\begin{array}{c}\text { USEPA } \\
\begin{array}{c}\text { Drinking Water } \\
\text { Standards }\end{array}\end{array}$} & \multicolumn{3}{|c|}{ Environmental quality standards Peru } \\
\hline & & Paca & Tragadero & & & $\begin{array}{l}\text { Drinking } \\
\text { water }\end{array}$ & $\begin{array}{c}\text { Water for fish } \\
\text { culture }\end{array}$ & $\begin{array}{l}\text { Water for } \\
\text { irrigation }\end{array}$ \\
\hline \multirow{3}{*}{$\mathrm{Pb}$} & Rank & $0.007-0.016$ & $0.009-0.026$ & & & & & \\
\hline & Mean \pm SD & $0.012 \pm 0.002$ & $0.019 \pm 0.005$ & 2.00 & 1.00 & 2.00 & 0.2 & 0.2 \\
\hline & $\mathrm{CV}$ & 18.94 & 24.79 & & & & & \\
\hline \multirow{3}{*}{$\mathrm{Zn}$} & Rank & $0.074-0.086$ & $0.064-0.092$ & & & & & \\
\hline & Mean \pm SD & $0.008 \pm 0.004$ & $0.079 \pm 0.008$ & 0.01 & 0.00 & 0.01 & 0.0025 & 0.05 \\
\hline & $\mathrm{CV}$ & 5.5 & 10.48 & & & & & \\
\hline \multirow{3}{*}{$\mathrm{Fe}$} & Rank & $0.018-0.024$ & $0.028-0.046$ & & & & & \\
\hline & Mean \pm SD & $0.022 \pm 0.002$ & $0.039 \pm 0.005$ & 3.00 & 5.00 & 3.00 & 1.00 & 2.00 \\
\hline & $\mathrm{CV}$ & 9.58 & 11.73 & & & & & \\
\hline \multirow{3}{*}{ As } & Rank & $0.013-0.005$ & $0.037-0.013$ & & & & & \\
\hline & Mean \pm SD & $0.004 \pm 0.001$ & $0.022 \pm 0.002$ & 0.01 & 0.00 & 0.01 & 0.1 & 0.1 \\
\hline & $\mathrm{CV}$ & 22.28 & 9.77 & & & & & \\
\hline
\end{tabular}




\subsection{Concentration of $\mathrm{Pb}, \mathrm{Zn}, \mathrm{Fe}$ and $\mathrm{As}$ in sediment from Paca and Tragadero Lagoons}

In relation to the concentration of elements in sediment in Paca and Tragadero (Table 3), the results show that $\mathrm{Pb}$ concentrations exceeded the standards for both lagoons, according to the Canadian standards for freshwater sediment (Canadian Council of Ministers of the Environment, 2001) that evaluate their biological impacts with $35 \mathrm{mg} \mathrm{kg}-1$ as the environmental quality standard (EQS). According to the sediment quality classification of Illinois in the United States (USEPA, 1984), the values found in the lagoons evaluated are high, in relation to the standard of $28 \mathrm{mg} \mathrm{kg}-1$, especially for Tragadero, although the values for both lagoons are different; while for the Australian and New Zealand, and Environment and Conservation Council (ANZECC and ARMCANZ, 2000), the values recorded are at the limit, in relation to the standard of $47 \mathrm{mg} \mathrm{kg}-1$. In the case of $\mathrm{Zn}$, the Canadian and Australian standards indicate that in both lagoons the values are lower than the EQS of 123 and $200 \mathrm{mg} \mathrm{kg}-1$, respectively. While for the US Environmental Protection Agency both lagoons are at the limit with an EQS of $80 \mathrm{mg} \mathrm{kg}-1$, although in contrast to what was recorded for $\mathrm{Pb}$, it is Paca that has a higher concentration of Zn (USEPA, 1984).

Table 3. Descriptive statistics of heavy metals and arsenic in sediment from Paca and Tragadero Lagoons in the Central Andes of Peru, expressed in mg kg-1.

\begin{tabular}{|c|c|c|c|c|}
\hline \multirow{2}{*}{ Element } & \multirow{2}{*}{ Descriptive statistics } & \multicolumn{2}{|c|}{ Lagoons } & \multirow{2}{*}{$\begin{array}{l}\text { ISQG Canadian interim } \\
\text { sediment quality guideline }\end{array}$} \\
\hline & & Paca & Tragadero & \\
\hline \multirow[b]{3}{*}{$\mathrm{Pb}$} & Rank & $35.56-53.96$ & $41.52-59.52$ & \multirow{3}{*}{18.70} \\
\hline & Mean \pm SD & $45.80 \pm 4.1$ & $49.71 \pm 5.53$ & \\
\hline & $\mathrm{CV}$ & 8.97 & 11.12 & \\
\hline \multirow{3}{*}{$\mathrm{Zn}$} & Rank & $67.62-105.52$ & $62.62-84.64$ & \multirow{3}{*}{30.20} \\
\hline & Mean \pm SD & $85.16 \pm 11.95$ & $71.59 \pm 6.71$ & \\
\hline & $\mathrm{CV}$ & 14.03 & 9.37 & \\
\hline \multirow{3}{*}{$\mathrm{Fe}$} & Rank & $7784-10875$ & 10659-21649 & \multirow{3}{*}{124.00} \\
\hline & Mean \pm SD & $9531 \pm 764$ & $17170 \pm 4340$ & \\
\hline & $\mathrm{CV}$ & 8.02 & 25.28 & \\
\hline \multirow{3}{*}{ As } & Rank & $10.35-17.53$ & $16.21-28.83$ & \multirow{3}{*}{7.24} \\
\hline & Mean \pm SD & $13.67 \pm 1.98$ & $22.99 \pm 3.64$ & \\
\hline & $\mathrm{CV}$ & 14.50 & 15.83 & \\
\hline
\end{tabular}

With respect to Fe, there are no standards reported for sediment quality. The As values found in Paca and Tragadero in comparison with Canadian and U.S. legislation (5.9 and $8 \mathrm{mg}$ $\mathrm{kg}-1$, respectively), indicate that the values are higher, with a higher concentration in Tragadero (22.99 mg kg-1) than in Paca (13.67 mg kg-1). Sediment concentrations in both lagoons showed that $\mathrm{As}$ and $\mathrm{Pb}$ at most points sampled exceeded Canadian, U.S. and Australian sediment quality standards, revealing that the concentrations of metals present in the sediments of these aquatic ecosystems are too high to cause adverse effects (Beiras et al., 2003).

Anthropogenic sources include mainly industrial activities and agricultural practices, such as the use of areas for tourist recreation in the Paca Lagoon; while in the Tragadero Lagoon, anthropogenic sources include mainly cleaning activities of automotive machinery with consequent waste of hydrocarbons, agricultural activity and textile washing.

\subsection{Concentration of $\mathrm{Pb}, \mathrm{Zn}, \mathrm{Fe}$ and As in leaves of Scirpus californicus from Paca and Tragadero Lagoons}

The results obtained (Table 4), show a remarkable capacity of Scirpus californicus "totora" 
to survive in environments with high loads of contaminating elements, especially $\mathrm{Pb}$ and $\mathrm{As}$. In Tragadero, very high values of $\mathrm{Pb}$ and As were recorded in sediment, which, considered as a substrate that comes into direct contact with the plant, differs from the quality standards, as well as in water, with different contamination origins, mainly anthropogenic.

Table 4. Descriptive statistics of heavy metals and arsenic in leaves of Scirpus californicus from Paca and Tragadero Lagoons in the Central Andes of Peru, expressed in mg kg-1.

\begin{tabular}{|c|c|c|c|c|c|}
\hline \multirow{2}{*}{ Element } & \multirow{2}{*}{ Descriptive statistics } & \multicolumn{2}{|c|}{ Lagoons } & \multirow{2}{*}{$\mathrm{NRC}$} & \multirow{2}{*}{ ANZECC } \\
\hline & & Paca & Tragadero & & \\
\hline \multirow{3}{*}{$\mathrm{Pb}$} & Rank & $0.004-0.020$ & $0.026-0.047$ & \multirow{3}{*}{0.1} & \multirow{3}{*}{0.01} \\
\hline & Mean \pm SD & $0.010 \pm 0.005$ & $0.034 \pm 0006$ & & \\
\hline & $\mathrm{CV}$ & 50.26 & 17.32 & & \\
\hline \multirow{3}{*}{$\mathrm{Zn}$} & Rank & $0.083-0.177$ & $0.121-0.356$ & \multirow{3}{*}{0.5} & \multirow{3}{*}{.--} \\
\hline & Mean \pm SD & $0.125 \pm 0.032$ & $0.192 \pm 0.068$ & & \\
\hline & $\mathrm{CV}$ & 25.85 & 35.34 & & \\
\hline \multirow{3}{*}{$\mathrm{Fe}$} & Rank & $0.010-0.026$ & $0.015-0.049$ & \multirow{3}{*}{0.5} & \multirow{3}{*}{.--} \\
\hline & Mean \pm SD & $0.016 \pm 0.004$ & $0.027 \pm 0.011$ & & \\
\hline & $\mathrm{CV}$ & 27.24 & 392.17 & & \\
\hline \multirow{3}{*}{ As } & Rank & $0.008-0.018$ & $0.011-0.020$ & \multirow{3}{*}{0.03} & \multirow{3}{*}{0.002} \\
\hline & Mean \pm SD & $0.013 \pm 0.003$ & $0.015 \pm 0.003$ & & \\
\hline & $\mathrm{CV}$ & 20.86 & 17.97 & & \\
\hline
\end{tabular}

NRC: National Research Council.

ANZECC: Australian and New Zealand, and Environment and Conservation Council.

The use of cattail leaves in the study areas is linked to livestock production, as animal feed, since the villagers cut the leaves and process them to add them to cattle feed. According to the National Research Council of the United States (NRC, 2005) animal tolerance to heavy metals for animal feed, $\mathrm{Pb}$ concentrations in cattail leaves were significantly below the maximum permitted limit of $0.1 \mathrm{mg} \mathrm{kg}-1$, while for the Australian and New Zealand, and Environment and Conservation Council (ANZECC) the concentration of $\mathrm{Pb}$ was within the limit for Paca, while Tragadero exceeded the maximum permissible value of $0.01 \mathrm{mg} \mathrm{kg}-1$. In the case of zinc concentration, according to the NRC, the maximum tolerable is $0.5 \mathrm{mg} \mathrm{kg}$ - 1 ; however, in both lagoons the concentration in the cattail leaves does not exceed this value, as well as in the case of Fe, whose maximum tolerable is $0.5 \mathrm{mg} \mathrm{kg}-1$. Regarding As concentrations in these leaves, it was found that both lagoons do not exceed the maximum permissible levels according to the NRC of $0.03 \mathrm{mg} \mathrm{kg}-1$; while for the ANZECC the maximum permissible level is $0.002 \mathrm{mg} \mathrm{kg}$ 1 , which is considered a high concentration. Consequently, cattail leaves should not be used in animal feed.

The concentrations of elements in cattail leaves in the lagoons were similar to those reported in other Andean environments, especially associated with environments with anthropogenic disturbance of mining origin, given the ability of the plant to adapt to environments with high loads of toxic element concentrations (Herrera et al., 2012; Juárez et $a l ., 2016)$. In environments highly affected by mining but with plants growing in littoral zones, leaf concentrations similar to those recorded in this study were reported in Lake Uru Uru, where concentrations of $\mathrm{As}=0.01 \mathrm{mg} \mathrm{kg}-1, \mathrm{~Pb}=0.02 \mathrm{mg} \mathrm{kg}-1, \mathrm{Zn}=0.16 \mathrm{mg} \mathrm{kg}-1$ and $\mathrm{Fe}=0.02 \mathrm{mg}$ kg-1 (Blanco, 2019), observing great similarity of concentrations of elements, considering that the Tragadero Lagoon has a strong agricultural pressure and polluting activities with 
hydrocarbons, differing from Paca Lagoon, whose pressure is tourist and from the Uru Uru Lake, where the pressure is mining.

The presence of toxic elements, such as $\mathrm{As}$ and $\mathrm{Pb}$ in the aquatic ecosystems of the Mantaro Valley, has been widely reported (Custodio et al., 2019), which implies that the natural riparian flora should have adapted to this circumstance over the years. On the other hand, the location of the lagoons increases toxicity, because they are close to urban areas and the activities of the populations, which pollute these aquatic ecosystems as a result of wastewater discharge, as well as transport vehicles with repercussions of $\mathrm{Pb}$ contamination in soils, due to the combustion of hydrocarbons (Saeedi et al., 2009; Custodio et al., 2020; Tapia, 2008).

\subsection{Bioaccumulation factor and bioconcentration of $\mathrm{Pb}, \mathrm{Zn}, \mathrm{Fe}$ and $\mathrm{As}$ in Paca and Tragadero Lagoons}

Table 5 shows the bioaccumulation factor (BAF) values for $\mathrm{Pb}, \mathrm{Zn}, \mathrm{Fe}$ and $\mathrm{As}$, sediment and Scirpus californicus. The mean $\mathrm{Pb}$ concentration was 0.0002 for Paca and 0.0007 for Tragadero. However, in Tragadero the results show a tendency to increase the concentration of $\mathrm{Pb}$ in sediment, whose values are close to 0.001. In the case of $\mathrm{Zn}$, the BAF for Paca was 0.0015, while for Tragadero it was 0.0027 , being the sediment concentrations in Paca significantly higher than in Tragadero.

Table 5. Bioaccumulation and bioconcentration factor of $\mathrm{Pb}, \mathrm{Zn}, \mathrm{Fe}$ and As from Paca and Tragadero Lagoons.

\begin{tabular}{|c|c|c|c|c|c|}
\hline \multirow{2}{*}{ Element } & \multirow{2}{*}{$\begin{array}{l}\text { Descriptive } \\
\text { statistics }\end{array}$} & \multicolumn{2}{|c|}{ Bioaccumulation } & \multicolumn{2}{|c|}{ Bioconcentration } \\
\hline & & Paca & Tragadero & Paca & Tragadero \\
\hline \multirow{2}{*}{$\mathrm{Pb}$} & Rank & $0.1 \times 10^{-3}-0.5 \times 10^{-3}$ & $0.5 \times 10^{-3}-1.0 \times 10^{-3}$ & $0.26-1.91$ & $1.19-3.62$ \\
\hline & Mean \pm SD & $0.2 \times 10^{-3} \pm 0.1 \times 10^{-3}$ & $0.7 \times 10^{-3} \pm 0.1 \times 10^{-3}$ & $0.87 \pm 0.45$ & $1.93 \pm 0.58$ \\
\hline \multirow{2}{*}{$\mathrm{Zn}$} & Rank & $1.0 \times 10^{-3}-1.9 \times 10^{-3}$ & $1.7 \times 10^{-3}-5.0 \times 10^{-3}$ & $1.00-2.37$ & $1.35-5.55$ \\
\hline & Mean \pm SD & $15 \times 10^{-3} \pm 0.2 \times 10^{-3}$ & $2.7 \times 10^{-3} \pm 0.8 \times 10^{-3}$ & $1.58 \pm 0.49$ & $2.50 \pm 1.10$ \\
\hline \multirow{2}{*}{$\mathrm{Fe}$} & Rank & $0.11 \times 10^{-5}-0.31 \times 10^{-5}$ & $0.09 \times 10^{-5}-0.43 \times 10^{-5}$ & $0.45-1.27$ & $0.36-1.42$ \\
\hline & Mean \pm SD & $0.18 \times 10^{-5} \pm 0.05 \times 10^{-5}$ & $0.18 \times 10^{-5} \pm 0.11 \times 10^{-5}$ & $0.77 \pm 0.24$ & $0.71 \pm 0.28$ \\
\hline \multirow{2}{*}{ As } & Rank & $0.6 \times 10^{-3}-1.4 \times 10^{-3}$ & $0.4 \times 10^{-3}-0.9 \times 10^{-3}$ & $1.68-7.20$ & $0.47-1.00$ \\
\hline & Mean \pm SD & $1.0 \times 10^{-3} \pm 0.3 \times 10^{-3}$ & $0.7 \times 10^{-3} \pm 0.1 \times 10^{-3}$ & $3.39 \pm 1.25$ & $0.67 \pm 0.12$ \\
\hline
\end{tabular}

The BAF of Fe from sediment to leaf were similar in both ponds with values of $0.18 \times 10$ 5. The BAF of As for Paca was $1.0 \times 10-3$, while for Tragadero it was $0.7 \times 10-3$. The concentration of heavy metals and As in sediment would not be a determinant for their accumulation in Scirpus californicus, since the BAF is low.

The bioconcentration factor (BCF) measures the capacity of a plant to bioconcentrate an element in its tissues, taking into account the concentration of that element in the water. For the case of Scirpus californicus, in both ponds it was found that the bioconcentration factors for $\mathrm{Fe}$ are not high (around 0.7). This result reveals that Scirpus californicus is not a good concentrator of $\mathrm{Fe}$ in relation to the concentration in water. However, the values of $\mathrm{Pb}$ and $\mathrm{Zn}$ in water are close to those reported in leaves, i.e., their bioconcentration level for these two elements is regular. On the other hand, for As, the bioconcentration factor of Scirpus californicus in Paca is the highest. It is three times higher than that recorded in water. 


\section{CONCLUSIONS}

The results of this study reveal the current status of the quality of the aquatic environment of natural wetlands in the central region of Peru in terms of heavy metals and arsenic.

The Paca and Tragadero Lagoons provide an important source of water for the populations of large cities in the central region of Peru. The presence of heavy metals and arsenic with great impact on the quality of these water bodies may be due to the pressure exerted by anthropogenic activities such as mining, agriculture, industrial and domestic wastewater.

The sediments of Paca and Tragadero Lagoons showed high concentrations of Fe, exceeding international standards (ISQG). Aquatic vegetation represented by Scirpus californicus in both lagoons bio accumulated mainly $\mathrm{Zn}$, without exceeding international standards (NRC y ANZECC). Therefore, our findings reveal the need to control the discharge of pollutants, improve the treatment of industrial and domestic wastewater, as it is of great importance to restore the health of lake ecosystems and reduce the risk of exposure of the population to toxic metals.

\section{REFERENCES}

ALTUN, Ö.; SAÇAN, M. T.; ERDEM, A. K. Water quality and heavy metal monitoring in water and sediment samples of the Küçükçekmece Lagoon, Turkey (2002-2003). Environmental Monitoring and Assessment, v. 151, n. 1-4, p. 345-362, 2009. https://doi.org/10.1007/s10661-008-0276-8

APHA; AWWA; WEF. Standard Methods for the examination of water and wastewater. 22nd ed. Washington, 2012. $1496 \mathrm{p}$.

ANZECC; ARMCANZ. Australian and New Zealand guidelines for fresh and marine water quality The Guidelines Australian and New Zealand Environment and Conservation Council Agriculture and Resource Management Council of Australia and New Zealand. National Water Quality Management Strategy, v. 1, n. 4, p. 314, 2000. Available at: https://www.waterquality.gov.au/anz-guidelines/resources/previous-guidelines/waterquality-monitoring. Access: Aug. 2021.

BEIRAS, R.; BELLAS, J.; FERNÁNDEZ, N.; LORENZO, J. I.; COBELO-GARCÍA, A. Assessment of coastal marine pollution in Galicia (NW Iberian Peninsula); metal concentrations in seawater, sediments and mussels (Mytilus galloprovincialis) versus embryo-larval bioassays using Paracentrotus lividus and Ciona intestinalis. Marine Environmental Research, v. 56, n. 4, p. 531-553, 2003. https://doi.org/10.1016/S01411136(03)00042-4

BLANCO, J. A. Suitability of Totora (Schoenoplectus californicus (C.A. Mey.) Soják) for Its Use in Constructed Wetlands in Areas Polluted with Heavy Metals. Sustainability, v. 11, n. 1, p. 1-22, 2019. https://doi.org/10.3390/su11010019

CANADIAN COUNCIL OF MINISTERS OF THE ENVIRONMENT. Canadian Sediment Quality Guidelines for the Protection of Aquatic Life: Summary tables. Winnipeg, 2001. p. 5.

CUSTODIO, M.; ÁlvareZ, D.; CUADRAdO, W.; MONTAlVO, R.; OCHOA, S. Potentially toxic metals and metalloids in surface water intended for human consumption and other uses in the Mantaro River watershed, Peru. Soil and Water Research, v. 2020, n. 1, p. 1-9, 2020. https://doi.org/10.17221/152/2019-swr 
CUSTODIO, M.; CUADRADO, W.; PEÑALOZA, R.; MONTALVO, R.; OCHOA, S.; QUISPE, J. Human risk from exposure to heavy metals and arsenic in water from rivers with mining influence in the Central Andes of Peru. Water (Switzerland), v. 12, n. 7, p. 1-20, 2020. https://doi.org/10.3390/w12071946

CUSTODIO, M.; MIRANDA, G.; PEÑALOZA, R.; DE LA CRUZ, H.; CHANAMÉ, F. Variability of the water quality characterizing high andean lagoons for tourist use evaluated through multivariate statistical methods, Junín, Peru. Journal of Ecological Engineering, v. 20, n. 8, p. 1-11, 2019. https://doi.org/10.12911/22998993/109800

FAYIGA, A. O.; SAHA, U. K. Arsenic hyperaccumulating fern: Implications for remediation of arsenic contaminated soils. Geoderma, v. 284, p. 132-143, 2016. https://doi.org/10.1016/j.geoderma.2016.09.003

FERNÁNDEZ, R.; ALBORNOZ, C.; LARSEN, K.; NAJLE, R. Bioaccumulation of heavy metals in Limnobium laevigatum and Ludwigia peploides: their phytoremediation potential in water contaminated with heavy metals. Environmental Earth Sciences, v. 77, n. 11, 2018. https://doi.org/10.1007/s12665-018-7566-4

HASSAN, M.; TANVIR RAHMAN, M. A. T. M.; SAHA, B.; KAMAL, A. K. I. Status of heavy metals in water and sediment of the Meghna River, Bangladesh. American $\begin{array}{lllllll}\text { Journal of Environmental Sciences, v. 11, n. } & \text { 6, } 2015 .\end{array}$ https://doi.org/10.3844/ajessp.2015.427.439

HERRERA, J.; CORRALES, J. R.; CAMPOS, J. M. C.; SILVA, V. S.; ALPIZAR, H. B. Evaluation of heavy metals in superficial sediments of Pirro river. Tecnología En Marcha, v. 26, p. 28-36, 2012. https://dx.doi.org/10.18845/tm.v26i1.1119

HOU, S.; ZHENG, N.; TANG, L.; JI, X.; LI, Y.; HUA, X. Pollution characteristics, sources, and health risk assessment of human exposure to $\mathrm{Cu}, \mathrm{Zn}, \mathrm{Cd}$ and $\mathrm{Pb}$ pollution in urban street dust across China between 2009 and 2018. Environment International, v. 128, p. 430-437, 2019. https://doi.org/10.1016/j.envint.2019.04.046

JUÁREZ, A.; ARRIBÉRE, M. A.; ARCAGNI, M.; WILliAMS, N.; RIZZO, A.; RIBEIRO GUEVARA, S. Heavy metal and trace elements in riparian vegetation and macrophytes associated with lacustrine systems in Northern Patagonia Andean Range. Environmental Science and Pollution Research, v. 23, n. 18, p. 17995-18009, 2016. https://doi.org/10.1007/s11356-016-6811-1

KARA, G. T.; KARA, M.; BAYRAM, A.; GÜNDÜZ, O. Assessment of seasonal and spatial variations of physicochemical parameters and trace elements along a heavily polluted effluent-dominated stream. Environmental Monitoring and Assessment, v. 189, n. 585, 2017. https://doi.org/10.1007/s10661-017-6309-4

KRUSKAL, W.; WALLIS, W. Use of ranks in one-criterion variance analysis. Journal of the American Statistical Association, v. 47, p. 583-621, 1952.

LIEBERMAN, P.; OGDEN, N. United States Patent (No 19). Washington, 1998.

MARTÍNEZ-LÓPEZ, S.; MARTÍNEZ-SÁNCHEZ, M. J.; GÓMEZ-MARTÍNEZ, M. DEL C.; PÉREZ-SIRVENT, C. Assessment of the risk associated with mining-derived arsenic inputs in a lagoon system. Environmental Geochemistry and Health, v. 42, n. 8, p. 2439-2450, 2020. https://doi.org/10.1007/s10653-019-00385-5 
MENDOZA-CARRANZA， M.; SEPÚLVEDA-LOZADA， A.; DIAS-FERREIRA， C.; GEISSEN, V. Distribution and bioconcentration of heavy metals in a tropical aquatic food web: A case study of a tropical estuarine lagoon in SE Mexico. Environmental Pollution, v. 20, p. 155-165, 2016. https://doi.org/10.1016/j.envpol.2015.12.014

MINAM. Decreto supremo Nº 004-2017-MINAM. EI Peruano, p. 6-9, 2017.

NRC. Mineral Tolerance of Animals. $2^{\text {nd }}$ ed. Washington, DC: The National Academies Press, 2005. https://doi.org/10.17226/11309

ODJER-BIO, N. T.; BELFORD, E. J. D.; ANSONG, M. What is happening to our Lagoons? The example of Butuah Lagoon in Ghana. International Journal of Energy and Environmental Engineering, v. 6, p. 183-193, 2015. https://doi.org/10.1007/s40095015-0165-1

OWOLABI, O. D.; AWODELE, O. Heavy metal bio-accumulation in the kidneys of scaly and non-scaly fishes from Epe Lagoon, Nigeria. Cuadernos de Investigacíon UNED, v. 11, n. 2, p. 201-211, 2019. https://doi.org/10.22458/urj.v11i2.2307

PERIS, M.; MICÓ, C.; RECATALÁ, L.; SÁNCHEZ, R.; SÁNCHEZ, J. Heavy metal contents in horticultural crops of a representative area of the European Mediterranean region. Science of The Total Environment, v. 378, n. 1-2, p. 42-48, 2007. https://doi.org/10.1016/j.scitotenv.2007.01.030

RODRÍGUEZ AYALA, S.; FLORES, R.; RODRÍGUEZ, M.; ROLDAN, D. Cuantificación de los factores de bioconcentración en Schoenoplectus californicus ubicada en el lago San Pablo, Imbabura-Ecuador (año, 2017). Ciencia, v. 20, n. 2, 2018. https://doi.org/10.24133/ciencia.v20i2.1213

SAEEDI, M.; HOSSEINZADEH, M.; JAMSHIDI, A.; PAJOOHESHFAR, S. P. Assessment of heavy metals contamination and leaching characteristics in highway side soils, Iran. Environmental Monitoring and Assessment, v. 151, n. 1-4, p. 231-241, 2009. https://doi.org/10.1007/s10661-008-0264-z

SANTORO, A.; BLO, G.; MASTROLITTI, S.; FAGIOLI, F. Bioaccumulation of heavy metals by aquatic macroinvertebrates along the Basento River in the South of Italy. Water, Air, and Soil Pollution, v. 201, p. 19-31, 2009. https://doi.org/10.1007/s11270-008-9923-5

SHAH, A. Q.; KAZI, T. G.; ARAIN, M. B.; JAMALI, M. K.; AFRIDI, H. I.; JALBANI, N.; BAIG, J. A.; KANDHRO, G. A. Accumulation of arsenic in different freshwater fish species - potential contribution to high arsenic intakes. Food Chemistry, v. 112, p. 520 524, 2009. http://dx.doi.org/10.1016/j.foodchem.2008.05.095

SINGH, A. K.; SRIVASTAVA, S. C.; VERMA, P.; ANSARI, A.; VERMA, A. Hazard assessment of metals in invasive fish species of the Yamuna River, India in relation to bioaccumulation factor and exposure concentration for human health Implications. Environmental Monitoring Assessment, v.186, n. 6, p. 3823-36, 2014. https://doi.org/10.1007/s10661-014-3660-6

SINGH, R. P. Effect of wastewater disposal and extent of industrial pollution in and around Kanpur, Uttar Pradesh, India. Bulletin of Engineering Geology and the Environment, v. 60 , n. 1, p. 31-35, 2001. https://doi.org/10.1007/s100640000079 
TAPIA, P. M. Diatoms as bioindicators of pollution in the Mantaro River, Central Andes, Peru. International Journal of Environment and Health, v. 2, n. 1, p. 82-91, 2008. https://doi.org/10.1504/IJENVH.2008.018674

URVIOLA, F. B. S. Determinación de metales pesados en las aguas del Río Ananea debido a la actividad minera aurífera, Puno-Perú. 2014 Inst. Revista de Investigaciones, v. 5, n. 4, 2009. https://doi.org/10.26788/epg.v5i4.14

USEPA. Evaluation of Illinois Stream Sediment Data. Washington, DC., 1984.

VOIGT, C. L.; DA SILVA, C. P.; DORIA, H. B.; RANDI, M. A. F.; DE OLIVEIRA RIBEIRO, C. A.; DE CAMPOS, S. X. Bioconcentration and bioaccumulation of metal in freshwater Neotropical fish Geophagus brasiliensis. Environmental Science and Pollution Research, v. 22, p. 8242-8252, 2015. https://doi.org/10.1007/s11356-014-39674 